Al-Bidayah : jurnal pendidikan dasar Islam

Volume 13, Number 1, June 2021

ISSN: 2549-3388 (online)

Available online at https://jurnal.albidayah.id

Submitted: January 29, 2021, Accepted: June 24, 2021

\title{
EFFECT OF CREATIVE INDEPENDENCE PROBLEM SOLVING (CIPS) BASED TRAINING MODULE ON PROFESSIONALISM OF RURAL INDONESIAN ELEMENTARY SCHOOL TEACHERS
}

\author{
Erni Munastiwi ${ }^{1}$, Jailani Md Yunos ${ }^{2}$, Maizam Alias ${ }^{3}$, Aini Nazura Paimin ${ }^{4}$ \\ UIN Sunan Kalijaga Yogyakarta, Indonesia ${ }^{1}$, \\ University Tun Hussein Onn Malaysia, Malaysia ${ }^{2,3,4}$ \\ E-mail: erni.munastiwi@uin-suka.ac.id ${ }^{1}$,jailani@uthm.edu.my², \\ maizam@uthm.edu.my ${ }^{3}$,nazura@uthm.edu.my ${ }^{4}$
}

DOI: 10.14421/al-bidayah.v13i1.616

\begin{abstract}
Training is needed to ensure that teachers acquire the knowledge necessary to teach problem-solving skills. Furthermore, a specifically designed training material such as a module is especially needed when teachers work in remote areas with fewer resources. Meanwhile, six educational problem-solving skills development needs among teachers in rural Indonesian elementary schools were identified: teacher mentoring, selfactualization, competency, creativity, problem-solving, and independence. A training module was designed based on the needs which were assessed using the CIPS model. The study aimed to investigate the effects of the CIPS-based Training Module on the professionalism of elementary school teachers. In addition, the training module consists of five (5) stages, which include pre-entering, plan, setting, action, and evaluation. The quasi-experimental research was conducted on 63 elementary teachers from Nunukan and Sebatik Island, North Kalimantan, Indonesia, assigned randomly to either an experiment or a control group. Before the training, a pre-test was conducted, followed by training using the module for the experiment groups, and no training for the control group. Furthermore, a post-test was conducted in both groups to identify the effectiveness of the training module. The independent sample t-test showed that the experimental group obtained a higher mean score than the control group. In conclusion, the CIPS-based Training Module effectively develops professionalism in teaching problem-solving skills among the experimental group's elementary teachers. Meanwhile, the study implies that rural elementary teachers need to be prepared to teach problem-solving skills.
\end{abstract}

\section{Keyword: elementary school; professional of teacher; training module}

\section{INTRODUCTION}

Today, the Industrial Revolution 4.0 has created the world with the change from an all-robotic world to an all-digital world. ${ }^{1}$ This Revolution 4.0 do only has an impact on changing the system of the community but also transforming the educational world. ${ }^{2}$ Also, since electronic-based learning applies digital learning, therefore teachers need to support electronic-based learning. ${ }^{3}$ Meanwhile, most teachers complained about

\footnotetext{
${ }^{1}$ A Hidayatullah, Digital Learning (Surabaya: UM Surabaya, 2018).

2 T Aagaard and A Lund, Digital Agency in Higher Education: Transforming Teaching and Learning (New York: Routledge, 2019).

${ }^{3}$ Abdeleh Bassam Al Amoush and Kamaljeet Sandhu, "Digital Innovation for Transformation of Learning Management Systems at Universities," chapter, Digital Innovations for Customer Engagement, Management, and Organizational Improvement (IGI Global, 2020), https://doi.org/10.4018/978-1-79985171-4.ch007.
} 
electronic-based learning because of several factors such as age, inadequate facilities, technology stuttering factors are caused by lack of devices, which, in turn, affects the professional level of teachers. ${ }^{4}$ Therefore CIPS-based training is conducted to improve teacher professionalism to fit the needs of education in the era of digitalization of education. In addition, teachers need to categorize the use of electronic learning as a form of digitalization. ${ }^{5}$

The rapid development of knowledge has led to improved quality of teaching to produce better and quality students in the future. ${ }^{6}$ Furthermore, qualified teachers become a vital need to create effective and creative learning. ${ }^{7}$ Also, each teacher needs to implement some characters such as problem-solving, creativity, and independent learning. Some of the factors that affect the character are such as activities, learning, resources for learning. ${ }^{8}$ Teachers need to be innovative and able to solve problems. ${ }^{9}$ For example, teachers who are creative in solving problems and ready to learn independently are good examples. The other example is using active learning. ${ }^{10}$ In addition, all those changes expect that they use collaborative learning to improve education. ${ }^{11}$

However, teachers have a problem with their creativity as they were too attached to their curriculum. They have always followed the proposed curriculum are not ready to

${ }^{4}$ M Ranieri, J Raffaghelli, and F Pezzati, "Digital Resources for Faculty Development in ELearning: A Self-Paced Approach for Professional Learning," Italian Journal of Educational Technology (IJET) 26, no. 1 (2018): 104-18, https://doi.org/DOI https://doi.org/10.17471/2499-4324/961.

${ }^{5}$ S Prestridge, "Categorising Teachers' Use of Social Media for Their Professional Learning: A SelfGenerating Professional Learning Paradigm," Computers and Education 129 (2019): 143-58, https://doi.org/10.1016/j.compedu.2018.11.003.

${ }^{6}$ Andreas Schleicher, Preparing Teachers and Developing School Leaders for the 21st Century, ed. Andreas Schleicher, International Summit on the Teaching Profession (OECD, 2012), 1-112, https://doi.org/10.1787/9789264174559-en.

${ }^{7}$ Marco Kools and Louise Stoll, What Makes A School A Learning Organisation? (OECD, 2017), https://www.oecd.org/education/school/school-learning-organisation.pdf.

${ }^{8}$ Samoekan Sophonhiranrak, Praweenya Suwannatthachote, and Sungworn Ngudgratoke, "Factors Affecting Creative Problem Solving in the Blended Learning Environment: A Review of the Literature," Procedia - Social and Behavioral Sciences 174, no. 1982 (February 2015): 2130-36, https://doi.org/10.1016/j.sbspro.2015.02.012.

${ }^{9}$ N V Belinova, "Innovation and Education: Technologies and Perspectives," Journal of Advanced Research in Dynamical and Control Systems 12, no. 4 (2020): 1307-13, https://doi.org/10.5373/JARDCS/V12SP4/20201607.

${ }^{10}$ S. Tientongdee, "Development of Problem-Solving Skill by Using Active Learning for Student Teachers in Introductory Physics," Journal of Physics: Conference Series 1144, no. 1 (December 2018): 012002, https://doi.org/10.1088/1742-6596/1144/1/012002.

${ }^{11}$ Inger Dagrunn Langset, Dan Yngve Jacobsen, and Halvdan Haugsbakken, "Digital Professional Development: Towards A Collaborative Learning Approach For Taking Higher Education Into The Digitalized Age," Nordic Journal of Digital Literacy 13, no. 01 (2018): 24-39, https://doi.org/10.18261/issn.1891-943x-2018-01-03. 
implement new things such as new learning strategies. ${ }^{12}$ Furthermore, this situation has led to low-quality teachers and hence affects the achievement of students. ${ }^{13}$ Furthermore, teachers need to improve pedagogy competencies to aid student performance. ${ }^{14}$ Meanwhile, designing a digital learning method is one of the efforts to improve pedagogical competence. ${ }^{15}$ Teachers do not have the spirit of self-learning because they depend solely on their facilities. Primarily when school did not provide educational facilities. ${ }^{16}$ This finding is in line with Ndjebakal Souck's research which revealed that school facilities affect the internal efficiency of the school. ${ }^{17}$ Therefore, a training module was developed based on the CIPS model. The researchers also have tested the effect on elementary teachers in North Kalimantan, Indonesia.

Education systems in Indonesia had been left behind like the government policies in the border region, especially in North Kalimantan in Indonesia had not been implemented in an integrated manner. According to the Central Statistics Agency of the Nunukan Region in North Kalimantan ${ }^{18}$, there was a lack of educational facilities and infrastructure identified in the region, resulting in poor performance and low-quality students and teachers. ${ }^{19}$

The creative Independent Problem Solving (CIPS) Model was the combination of two (2) models, which were Creative Problem Solving (CPS) and Independent Learning

${ }^{12}$ Alireza Hajiyakhchali, "The Effects of Creative Problem Solving Process Training on Academic Well-Being of Shahid Chamran University Students," Procedia-Social and Behavioral Sciences 84 (2013): 549-52, https://doi.org/10.1016/j.sbspro.2013.06.602; Rene Lopez Flores et al., "Collective Intelligence to Solve Creative Problems in Conceptual Design Phase," in Procedia Engineering, vol. 131 (Elsevier Ltd, 2015), 850-60, https://doi.org/10.1016/j.proeng.2015.12.394.

${ }^{13}$ Nia Juniarti, Yohanes Bahari, and Wanto Riva'ie, "Faktor Penyebab Menurunnya Hasil Belajar Siswa Pada Pembelajaran Sosiologi Di SMA," Jurnal Pendidikan Dan Pembelajaran Khatulistiwa 4, no. 2 (February 11, 2015): 1-11, https://jurnal.untan.ac.id/index.php/jpdpb/article/view/9025.

${ }^{14} \mathrm{~S}$ Syahruddin, A Ahdan, and E Ernawati, “Application of Online Mode Professional Development in Enhancing Pedagogical and Professional Competencies in Early Grade Primary School Teacher," JPP (Jurnal Pendidikan Dan Pembelajaran) 26, no. 1 (2019): 36-42, http://dx.doi.org/10.17977/um047v26i12019p036.

${ }^{15}$ Ranieri, Raffaghelli, and Pezzati, "Digital Resources for Faculty Development in E-Learning: A Self-Paced Approach for Professional Learning."

${ }^{16}$ Suci Rahmiga, "Kurangnya Sarana Dan Prasarana Belajar Di Sekolah” (INA-Rxiv, December 6, 2019), https://doi.org/10.31227/osf.io/5ckxs.

${ }^{17}$ Emmanuel Ndjebakal Souck and Genevarius Nji, "The Effects of School Facilities on Internal Efficiency: The Case of Selected Bilingual Secondary Schools in Yaounde Centre," World Journal of Research and Review (WJRR) 4, no. 4 (April 2017): 41-48, https://www.wjrr.org/download_data/WJRR0404008.pdf.

18 BPS Nunukan, "Badan Pusat Statistik Kabupaten Nunukan," accessed January 29, 2021, https://nunukankab.bps.go.id/.

${ }^{19}$ BPS, "Badan Pusat Statistik Kabupaten Nunukan,” Badan Pusat Statistik, 2016. 
(IL). ${ }^{20}$ This model was an approach to improve the quality of learning through problemsolving, creativity, and independence in the process of learning. Furthermore, the principles for implementing this model were flexible and focused on students' needs, efficient learning, independent teachers who were creative and able to solve learning problems. In addition, the CPIS model had four (4) characteristics, namely creative planning and implementation, innovative and fun learning, independent teachers, and continuous improvement. ${ }^{21}$

Based on Linda Febriani's research, which shows that its model can be applied in learning. ${ }^{22}$ The CIPS-based learning design starts from planning to the evaluation of learning. ${ }^{23}$ In addition, Gilhooly's research shows that creative thinking in problemsolving is essential. ${ }^{24}$ Meanwhile, Althuizen Niek's research shows that creative problemsolving achievement can use a case-based reasoning system. ${ }^{25}$ As a result of the training and experience of teachers, their professionalism is increased. ${ }^{26}$

The training module based on the CIPS model consists of five (5) stages, namely pre-entering, plan, setting, action, and evaluation. Stage 1, the pre-entering, was the initial process of mapping before the planning stage, and its activities include mapping students, field conditions, setting goals, and exploring the learning resources according to the learning environment. Stage 2, which is the plan, consists of four (4) aspects which are i) arranged and developed lesson plan, ii) learning media (Audio, Visual and Audiovisual learning media), iii) learning strategies (Problem-Based, Inquiry and Project-based learning strategies) and iv) developed evaluation tools. Stage 3 is a setting that consists of establishing suitable facilities, such as media and a learning environment. Stage 4 is an

${ }^{20}$ Kenneth J. Gilhooly, "Incuba Action and Intuition in Creative Problem Solving," Frontiers in Psychology 7 (July 2016): 1076, https://doi.org/10.3389/fpsyg.2016.01076.

${ }^{21}$ Erni Munastiwi et al., "The Spending Developing Training Material Based on Creative Problem Solving and Independent Learning for Remote Area Teachers," Solid State Technology, November 1, 2020, 9189-98, http://www.solidstatetechnology.us/index.php/JSST/article/view/5591.

${ }^{22}$ Linda Pebriani et al., "Creative and Innovative Problem Solving (Cips) Dalam Pembelajaran Matematika Berbasis Mnr (Matematika Nalaria Realistik)," Transformasi : Jurnal Pendidikan Matematika Dan Matematika 4, no. 2 (2020): 331-46, https://doi.org/10.36526/tr.v4i2.977.

${ }^{23}$ Erni Munastiwi, Model - Model Pembelajaran CIPS (Creative, Independent, Problem Solving), (Jakarta: Rajawali Press, 2020).

${ }^{24}$ Gilhooly, "Incuba Action and Intuition in Creative Problem Solving."

${ }^{25}$ Niek Althuizen and Berend Wierenga, "Supporting Creative Problem Solving with a Case-Based Reasoning System," Journal of Management Information Systems 31, no. 1 (July 2014): 309-40, https://doi.org/10.2753/MIS0742-1222310112.

26 Sahari Sahari, "Pengaruh Pendidikan, Pelatihan, Dan Pengalaman Mengajar Terhadap Profesionalisme Guru Di SMAN I Likupang," Jurnal Ilmiah Iqra' 9, no. 1 (2018): 62-86, https://doi.org/10.30984/jii.v9i1.599. 
action that included the nine steps to run the model in the teaching process. Lastly, stage 5 evaluates initial mapping, planning, learning settings, and implementation process. Table 1 summarizes the five (5) stages of implementation of the CIPS-based Training Module.

Table 1

CIPS-based Training Module

\begin{tabular}{|c|c|c|c|c|c|}
\hline \multirow{3}{*}{ 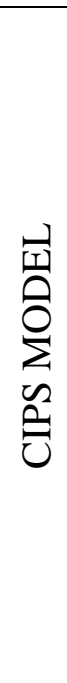 } & Pre entering & Plan & Setting & Action & Evaluation \\
\hline & Teacher & Teacher & Teacher & $\begin{array}{c}\text { Teacher and } \\
\text { Student }\end{array}$ & $\begin{array}{l}\text { Teacher and } \\
\text { Principal }\end{array}$ \\
\hline & $\begin{array}{l}\text { Mapping } \\
\text { students, field } \\
\text { conditions, } \\
\text { setting goals, } \\
\text { and exploring } \\
\text { the learning } \\
\text { resources } \\
\text { according to } \\
\text { the learning } \\
\text { environment }\end{array}$ & $\begin{array}{l}\text { Arranged and } \\
\text { developed } \\
\text { lesson plan, } \\
\text { learning } \\
\text { media, } \\
\text { learning } \\
\text { strategies, } \\
\text { and } \\
\text { developed } \\
\text { evaluation } \\
\text { tools }\end{array}$ & $\begin{array}{l}\text { Setting up } \\
\text { facilities, } \\
\text { media, and } \\
\text { learning } \\
\text { environment } \\
\text { that suitable } \\
\text { for learning }\end{array}$ & $\begin{array}{c}\text { Make an } \\
\text { enjoy } \\
\text { learning }\end{array}$ & $\begin{array}{c}\text { Evaluation of } \\
\text { learning } \\
\text { process }\end{array}$ \\
\hline
\end{tabular}

\section{RESEARCH METHODS}

The method used was the quasi-experimental research design. ${ }^{27}$ The sample consisted of 63 elementary teachers from SDIT Cahaya Ibadurrahman, SD Teladan Prima Bukit Permata, SD Teladan Prima Sawit, SD Teladan Prima 01 Talisyan from Nunukan Island, and Sebatik Island, North Kalimantan, Indonesia. The samples were randomly assigned to experimental $(n=33)$ and control $(n=30)$ groups. Before implementing the CIPS-based Training Module to the experimental groups, a pre-test was conducted for the experimental and control groups, which was carried out to determine the prior knowledge of the elementary teachers. Afterward, the training module was then conducted in experiment groups, but the control groups continued the teaching and learning process without training. After implementing the training module, a post-test was conducted on both groups to identify the effect after the training module. Research procedures for using CIPS model training are conducted by providing pre-test questionnaires, conducting training activities on teachers using the CIPS models, and re-

27 Sugiyono, Metode Penelitian Pendidikan Pendekatan Kuantitatif, Kualitatif, Dan $R \& D$ [Research Methods of Education Quantitative, Qualitative, and $R \& D$ Approach], 22nd ed. (Bandung: Alfabeta, 2015). 
examining with questioners three months after the training. In addition, questionnaires were given to respondents of experimental and control classes.

A 5-Likert scale questionnaire was used to measure the effect of the CIPS-based Training Module. ${ }^{28}$ Furthermore, it consists of six (6) sections: Teacher Mentoring, Selfactualization, Competency, Creativity, Problem Solving, and Independence. Table 2 shows the total items for each section and the value of Cronbach's Alpha.

Table 2

Reliability estimates (Cronbach Alpha) of Items on the Questionnaire

\begin{tabular}{cccc}
\hline No & Section & Item & $\alpha$ \\
\hline 1 & Teacher Mentoring & 23 & .891 \\
2 & Self-actualization & 20 & .879 \\
3 & Competency & 13 & .894 \\
4 & Creativity & 12 & .874 \\
5 & Problem Solving & 12 & .896 \\
6 & Independence & 12 & .885 \\
\hline
\end{tabular}

The descriptive (mean and standard deviation) and inferential analysis (independent sample t-test) were used to analyze the research question to identify the effect of the CIPSbased Training Module among elementary school teachers in North Kalimantan, Indonesia.

A pilot test was conducted to test the reliability of the questionnaire that was used. This test was essential to make sure that the questionnaire used was able to measure the variables that need to be identified, and the results showed that the value of Cronbach's Alpha obtained was larger than .80 , which indicated that each construct was good and can be used to measure the assigned variables. ${ }^{29}$ Hence, this study proceeds in investigating the effects of the CIPS-based Training Module on professional elementary teachers.

\section{RESULT AND DISCUSSION}

The pre-test results showed that both groups are equivalent based on the independent sample t-test results shown in Table 3, and therefore, we compared the posttest to determine the effectiveness of the training module.

${ }^{28}$ Ankur Joshi et al., "Likert Scale: Explored and Explained," British Journal of Applied Science \& Technology 7, no. 4 (2015): 396-403, https://doi.org/10.9734/bjast/2015/14975.

29 Chua Yan Piaw, Kaedah Dan Statistik Penyelidikan: Kaedah Penyelidikan - UM Research Repository, McGraw-Hill Education., 2nd ed. (Malaysia: Graw-Hill Education, 2011). 
Table 3

Pre-test comparison between control and experimental group

\begin{tabular}{|c|c|c|c|c|c|c|}
\hline & \multirow[b]{2}{*}{ Construct } & \multicolumn{2}{|c|}{$\begin{array}{c}\text { Levene's Test for } \\
\text { Equality of } \\
\text { Variances }\end{array}$} & \multicolumn{3}{|c|}{$\begin{array}{l}\text { t-test for Equality of } \\
\text { Means }\end{array}$} \\
\hline & & $\mathrm{F}$ & $\mathrm{P}$ & $\mathrm{t}$ & df & $\begin{array}{c}\mathrm{P} \\
(2- \\
\text { tailed })\end{array}$ \\
\hline Teacher & Equal variances assumed & 6.608 & .013 & -1.423 & 61 & .160 \\
\hline Mentoring & Equal variances not assumed & & & -1.377 & 38.89 & .176 \\
\hline Self- & Equal variances assumed & 10.831 & .002 & 1.170 & 61 & .247 \\
\hline actualization & Equal variances not assumed & & & 1.120 & 32.04 & .271 \\
\hline \multirow{2}{*}{ Competency } & Equal variances assumed & 29.414 & .000 & 2.013 & 61 & .049 \\
\hline & Equal variances not assumed & & & 1.922 & 30.29 & .064 \\
\hline \multirow{2}{*}{ Creativity } & Equal variances assumed & .351 & .556 & .216 & 61 & .830 \\
\hline & Equal variances not assumed & & & .213 & 52.44 & .832 \\
\hline Problem & Equal variances assumed & 12.129 & .001 & -.042 & 61 & .966 \\
\hline Solving & Equal variances not assumed & & & -.041 & 34.08 & .968 \\
\hline \multirow{2}{*}{ Independence } & Equal variances assumed & 17.117 & .000 & -1.069 & 61 & .289 \\
\hline & Equal variances not assumed & & & -1.027 & 33.83 & .312 \\
\hline
\end{tabular}

The independent sample t-test showed that the pre-test for both the experimental and control groups was not significant. This test was indicating that they are at the same level of knowledge before the treatment was conducted. Hence, the training module was conducted, and the effectiveness was identified.

This research used descriptive analysis (mean \& standard deviation) and an independent-sample t-test to identify the effects of CIPS-based Training Module on primary school teachers in both experimental and control groups. The results showed that the mean score for each construct for the experimental group was higher than that of the control group. Creativity construct obtained the highest mean scores among both experimental $(\mathrm{M}=3.75$ and $\mathrm{SD}=.44)$ and control $(\mathrm{M}=3.11$ and $\mathrm{SD}=.51)$ groups.

The overall result shows that the CIPS-based Training Module given to the experimental group positively affected primary school teachers in the concept of Mentoring, Self-actualization, Competency, Creativity, Problem Solving, and Independence constructs. Therefore, the mean score analysis results for each construct and the difference are shown in table 4 and figure 1 , respectively. 
Table 4

Different of Mean Score by Constructs

\begin{tabular}{lllll}
\hline \multicolumn{1}{c}{ Construct } & \multicolumn{1}{c}{ Group } & $\mathrm{N}$ & $\mathrm{M}$ & $\mathrm{SD}$ \\
\hline Teacher Mentoring & Experiment & 33 & 3.55 & .50 \\
& Control & 30 & 3.00 & .48 \\
Self-actualization & Experiment & 33 & 3.69 & .38 \\
& Control & 30 & 3.02 & .46 \\
Competency & Experiment & 33 & 3.75 & .44 \\
\multirow{5}{*}{ Creativity } & Control & 30 & 3.11 & .51 \\
\multirow{2}{*}{ Problem Solving } & Experiment & 33 & 3.59 & .54 \\
& Control & 30 & 2.93 & .52 \\
Independence & Experiment & 33 & 3.72 & .49 \\
& Control & 30 & 3.08 & .53 \\
& Experiment & 33 & 3.70 & .54 \\
\hline
\end{tabular}

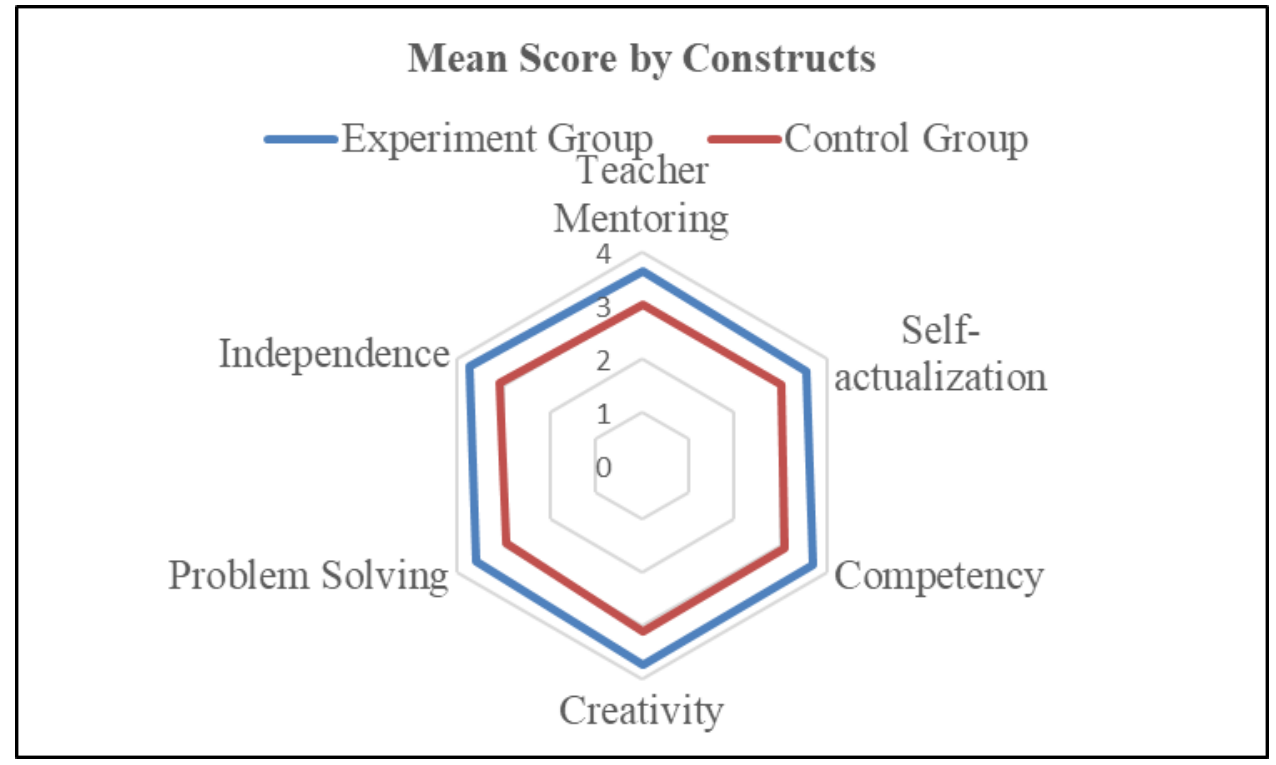

Figure 1

Difference between Experiment Group and Control Group

This research used an independent-sample t-test to identify the mean score differences for Teacher Mentoring, Self-actualization, Competency, Creativity, Problem Solving, and Independence constructs for treatment and control groups after training. Meanwhile, we used the sample t-test for examining the value of Levene's test for equality of variances. Therefore, when the p-value was not significant and greater than .05 , then the two groups were considered the same, and this research used data analysis in the first row.

The results of the independent $t$-test showed that there was a significant difference between the experimental $(\mathrm{M}=3.55, \mathrm{SD}=.50)$ and control group $(\mathrm{M}=3.00, \mathrm{SD}=.48)$ for the teacher mentoring construct, $\mathrm{t}(61)=4.434, \mathrm{p}=.000$, there was a significant difference between the experimental $(\mathrm{M}=3.69, \mathrm{SD}=0.38)$ and control group $(\mathrm{M}=3.02$, 
$\mathrm{SD}=.46)$ for self-actualizing constructs, $\mathrm{t}(61)=6.242, \mathrm{p}=.000$, and there were also significant differences between the experimental $(\mathrm{M}=3.75, \mathrm{SD}=.44)$ and control group $(\mathrm{M}=3.11, \mathrm{SD}=.51)$ for competency constructs; $\mathrm{t}(61)=5.359, \mathrm{p}=.000$.

Subsequently, there was a significant difference between the experimental $(\mathrm{M}=$ $3.59, \mathrm{SD}=.54)$ and control group ( $\mathrm{Min}=2.93, \mathrm{SP}=0.52)$ for the construct of creativity, $\mathrm{t}(61)=4.979, \mathrm{p}=.000$, there was a significant difference between experimental $(\mathrm{M}=$ $3.72, \mathrm{SD}=.49)$ and control group $(\mathrm{M}=3.08, \mathrm{SD}=.53)$ for problem solving constructs; $\mathrm{t}$ $(61)=4.963, p=.000$ and finally there was a significant difference between the experimental $(\mathrm{M}=3.70, \mathrm{SD}=.54)$ and control group $(\mathrm{M}=3.06, \mathrm{SD}=.51)$ for the Independence construct, $\mathrm{t}(61)=4.772, \mathrm{p}=.000$. In general, the experimental group achieved higher mean scores than the control group.

In summary, we have discovered that the CIPS-based Training Module provided to the experimental group positively affects primary school teachers in mentoring, Selfactualization, Competency, Creativity, Problem Solving, and Independence constructs. Table 5 shows a summary of the analysis.

Table 5

Independent-sample t-test

\begin{tabular}{|c|c|c|c|c|c|c|}
\hline & \multirow{2}{*}{ Construct } & \multicolumn{2}{|c|}{$\begin{array}{c}\text { Levene's Test } \\
\text { for Equality of } \\
\text { Variances }\end{array}$} & \multicolumn{3}{|c|}{ t-test for Equality of Means } \\
\hline & & $\mathrm{F}$ & $\begin{array}{c}\text { P- } \\
\text { value }\end{array}$ & $\mathrm{t}$ & df & $\begin{array}{c}\text { P-value } \\
\text { (2- } \\
\text { tailed) }\end{array}$ \\
\hline \multirow{2}{*}{$\begin{array}{c}\text { Teacher } \\
\text { Mentoring }\end{array}$} & Equal variances assumed & .145 & .705 & 4.434 & 61 & .000 \\
\hline & Equal variances not assumed & & & 4.443 & 60.817 & .000 \\
\hline \multirow{2}{*}{$\begin{array}{c}\text { Self- } \\
\text { actualization }\end{array}$} & Equal variances assumed & .047 & .829 & 6.242 & 61 & .000 \\
\hline & Equal variances not assumed & & & 6.183 & 56.244 & .000 \\
\hline \multirow{2}{*}{ Competency } & Equal variances assumed & .002 & .961 & 5.359 & 61 & .000 \\
\hline & Equal variances not assumed & & & 5.321 & 57.554 & .000 \\
\hline \multirow{2}{*}{ Creativity } & Equal variances assumed & .861 & .357 & 4.979 & 61 & .000 \\
\hline & Equal variances not assumed & & & 4.987 & 60.731 & .000 \\
\hline \multirow{2}{*}{$\begin{array}{l}\text { Problem } \\
\text { Solving }\end{array}$} & Equal variances assumed & .173 & .679 & 4.963 & 61 & .000 \\
\hline & Equal variances not assumed & & & 4.945 & 59.184 & .000 \\
\hline \multirow{2}{*}{ Independence } & Equal variances assumed & .487 & .488 & 4.772 & 61 & .000 \\
\hline & Equal variances not assumed & & & 4.783 & 60.867 & .000 \\
\hline
\end{tabular}


Based on implementing the CIPS-based Training Module, the teachers undergo five (5) stages: pre-entering, plan, setting, action, and evaluation. Consequently, teachers who have learned with the CIPS-based Training Module can improve their creativity in teaching strategies to make innovation and create an innovative learning media for students. ${ }^{30}$ In addition, teachers can also implement different teaching methods in each subject and deliver the teaching materials better ${ }^{31}$. Moreover, a creative teacher enhances student's achievement as the teachers are aware of each student's needs and can create an exciting environment for learning ${ }^{32}$. In conclusion, the teacher's creativity increased with implementing the CIPS-based Training Module and positively affected students in the future.

The CIPS-based Training Module's positive effect increased teachers' skills in creativity, independence, competency, Mentoring, problem-solving, and selfactualization. According to Dobbins, teachers were very limited in their creativity, but their skills increased when they implemented the training module. ${ }^{33}$ Hence, it helps the teacher to implement more engaging activities in their teaching and learning process ${ }^{34}$. The CIPS model adopted in the training module enhanced teacher's creativity in teaching strategies such as diversity of teaching methods, ${ }^{35}$ innovation in learning media, creating interactive environments for students learning, and delivering teaching materials better. ${ }^{36}$

The development of the quality of teacher skills requires regular teacher mentoring. ${ }^{37}$ Training conducted on teachers can make teachers able to play a good role

${ }^{30}$ D. Kalyani and K. Rajasekaran, "Innovative Teaching and Learning," Journal of Applied and Advanced Research 3, no. S1 (May 10, 2018): 23, https://doi.org/10.21839/jaar.2018.v3is1.162.

31 Peter Woods, Creative Teachers in Primary Schools, Creative Teachers in Primary Schools (London: Taylor and Francis, 2019), https://doi.org/10.4324/9780429326639; Shu Chiu Liu and Huann shyang Lin, "Primary Teachers' Beliefs about Scientific Creativity in the Classroom Context," International Journal of Science Education 36, no. $10 \quad$ (2014): 1551-67, https://doi.org/10.1080/09500693.2013.868619.

${ }^{32}$ Dan Davies et al., "Creative Learning Environments in Education-A Systematic Literature Review," Thinking Skills and Creativity 8, no. 1 (April 2013): 80-91, https://doi.org/10.1016/j.tsc.2012.07.004.

${ }^{33}$ Kerry Dobbins, "Teacher Creativity within the Current Education System: A Case Study of the Perceptions of Primary Teachers," Education 3-13 37, no. 2 (2009): 95-104, https://doi.org/10.1080/03004270802012632.

${ }^{34}$ Kalyani and Rajasekaran, "Innovative Teaching and Learning."

35 Ronald A. Beghetto and James C. Kaufman, "Classroom Contexts for Creativity," High Ability Studies 25, no. 1 (2014): 53-69, https://doi.org/10.1080/13598139.2014.905247.

36 Beghetto and Kaufman, "Classroom Contexts for Creativity."

37 Asep Zuhara Argawinata, "Manajemen Pendampingan Guru Untuk Meningkatkan Kompetensi Pedagogik Dan Profesional Guru-Guru Mata Pelajaran Sekolah Menengah Pertama Di Kota Bandung," Jurnal Mitra Swara Ganesha 3, no. 1 (January 29, 2016), http://ejournal.utp.ac.id/index.php/JMSG/article/view/467. 
in teaching, and through mentoring, educators help find students' learning problems and difficulties, obtain and reflect on the problem-solving solutions. ${ }^{38}$ Thus, teacher mentoring is expected to guide, support, direct, and develop teacher competence, build confidence and a sense of belonging to the teacher's profession. The results showed that both less experienced teachers and mentors who did not participate in the mentoring developed low self-esteem, and they preferred to leave their teaching jobs because of stress, frustration, dissatisfaction, and incompetence that affected their confidence. While teachers that have participated in mentoring develop confidence, acquire leadership and communication skills, they become empathetic, feel valued and have the ability to function independently as classroom teachers. ${ }^{39}$

The description of self-actualization is loosely the full use and exploitation of talents, capabilities, and potentialities. Such people seem to be fulfilling themselves and doing the best that they are capable of doing. ${ }^{40}$ Their love for educating the students becomes based on the actualization of teachers in teaching. ${ }^{41}$ Therefore, building the quality and love of teachers to the teaching profession needs to be based on competency development.

Training material based on the CIPS model develops teacher creativity in teaching, an essential point in CIPS training. Previous studies convey several factors that influence creative teachings, such as (a) personality traits, including perseverance, willingness to develop, acceptance of new experiences, self-confidence, sense of humor, curiosity, depth of ideas, and imagination. (b) family factors, which include how to teach an open and tolerant child, and the creative performance of parents. (c) growth and educational experiences, which include homemade games and stories, and brainstorming between classmates. (d) confidence in teaching, hard work, motivation, and (e) the administrative side of the school organization. Among these factors, confidence in

\footnotetext{
${ }^{38}$ Erliany Syaodih and Cucu Lisnawati, "Pendampingan Guru Dalam Menemukan Dan Mengatasi Kesulitan Belajar Siswa Di Mts Miftahulfallah Bandung," Educare, December 31, 2018, 8-11, http://jurnal.fkip.unla.ac.id/index.php/educare/article/view/223.

${ }^{39}$ Mary Achenushure Abetang, Romano Nereo Oguma, and Akpenka Pius Abetang, "Mentoring And The Difference It Makes In Teachers' Work: A Literature Review," European Journal of Education Studies 7, no. 6 (June 26, 2020), https://doi.org/10.46827/ejes.v7i6.3146.

40 Stanley D. Ivie, "Self-Actualization: Its Use and Misuse in Teacher Education," Journal of Teacher Education 33, no. 5 (July 2, 1982): 24-27, https://doi.org/10.1177/002248718203300506.

41 Prakash Chandra Jena and Rinzin Dorji, "Self-Actualization And Value Orientation Among Primary School Teachers In Bhutan," World Scientific News, no. 54 (2016): 217-39, https://www.infona.pl//resource/bwmeta1.element.psjd-bd1625f8-4733-4c1b-9c18-a171f38fecc5.
} 
teaching, hard work, and motivation are the main aspects. ${ }^{42}$ With CIPS training, teaching creativity in rural schools in North Kalimantan, especially Sebatik-Nunukan island, provided creative opportunities for teaching students.

In addition, the independent skills of elementary teachers also increase after the implementation of the CIPS-based Training Module. Therefore, when teachers were independent in their teaching process, they were more aware of creating new strategies and solving problems using their ways. ${ }^{43}$ Independent teachers improve the quality of their achievement and produce quality students in the future. ${ }^{44}$ Teachers also become independent in planning their teaching process and deciding how to make their teaching enjoyable using suitable learning material. In general, the training module has a significant impact on teachers and students in the future.

Competence has an explicit definition. Definition of competence is knowledge, skills, abilities, or traits associated with high devotion to a job. ${ }^{45}$ Therefore, teacher's competencies are identified as the most effective contribution to support student achievement, ${ }^{46}$ which is essential for teacher education and professional development. ${ }^{47}$ Thus, through CIPS training, teachers can plan the learning that they will undertake in the classroom, conduct learning that provides the most significant opportunity for learners to explore the abilities and skills that exist in them, as well as to conduct evaluations that not only focus on one aspect of cognitive but also evaluate the affective and psychomotor aspects of learners. ${ }^{48}$

Subsequently, problem-solving for each teacher also improved as they went through the CIPS-based Training Module. The teachers can guide students in solving

42 Jeou-Shyan Horng et al., "Creative Teachers and Creative Teaching Strategies," International Journal of Consumer Studies 29, no. 4 (2005): 352-58, https://doi.org/10.1111/j.1470-6431.2005.00445.x.

${ }^{43}$ Mukhtar, "Strategi Kepala Sekolah Dalam Meningkatkan Kinerja Guru Pada SMP Negeri Di Kecamatan Masjid Raya Kabupaten Aceh Besar," Jurnal Administrasi Pendidikan: Program Pascasarjana Unsyiah 3, no. 3 (January 1, 2015), http://jurnal.unsyiah.ac.id/JAP/article/view/2873.

${ }^{44}$ Robert A. Duke, “Their Own Best Teachers," Music Educators Journal 99, no. 2 (December 9, 2012): 36-41, https://doi.org/10.1177/0027432112458956.

${ }^{45}$ Hamidulloh Ibda, "Peningkatan Kompetensi Profesional Guru SD/MI Melalui Menulis Di Media," Tarbawi: Jurnal Pendidikan Islam 14, no. 1 (2017): 45-62, https://doi.org/10.34001/tarbawi.v14i1.610.

46 Mohd Yusri Ibrahim et al., "Communication Skills: Top Priority of Teaching Competency," International Journal of Learning, Teaching and Educational Research 18, no. 8 (2019): 17-30, https://doi.org/10.26803/ijlter.18.8.2.

${ }^{47}$ Nam-Hwa Kang et al., "Teacher Competency in Competency-Focused Science Teaching in the South Korean Context: Teacher Self-Assessment Instrument Development and Application," Asia-Pacific Science Education 6, no. 2 (December 17, 2020): 480-513, https://doi.org/10.1163/23641177-bja10012.

${ }^{48}$ Kang et al. 
problems in the learning process and give a fair assessment to their students. ${ }^{49}$ They also overcome barriers in teaching, such as learning media and resources to teach their students. ${ }^{50}$ Hence, students were ready and motivated as their teachers were able to solve their problems quickly.

\section{CONCLUSION}

The study aims to determine the effectiveness of the CIPS-based Training Module in improving teacher's professionalism in creativity, problem-solving, and independent skills. The result showed that the competence of elementary teachers in problem-solving is enhanced using the CHIPS-based training module. It also showed that Training Module positively affects elementary teachers from all aspects, namely, Teacher Mentoring, SelfActualization, Competence, Creativity, Problem Solving, and Independence. Hence, this CIPS-based Training Module needs to be implemented longer in the future to ensure that the consequence has a more significant impact on teachers and students. Therefore, the recommendation aims to develop CIPS training modules in various areas of education, not only in elementary schools.

\section{ACKNOWLEDGMENTS}

Thank you to Institution: UIN Sunan Kalijaga Yogyakarta, Indonesia and Universiti Tun Hussein Onn Malaysia (UTHM).

\section{DECLARATION OF CONFLICTING INTERESTS}

The author/s declared no potential conflicts of interest with respect to the research, authorship, and/or publication of this article.

\section{FUNDING}

This research obtained financing from the Research and Community Service Institute (LPPM) of Universitas Islam Negeri (UIN) Sunan Kalijaga Yogyakarta through Rector Decree No. 106.10 of 2019.

${ }^{49}$ Rina Wahyuni and Teti Berliani, "Pelaksanaan Kompetensi Pedagogik Guru Di Sekolah Dasar," Sekolah Dasar: Kajian Teori Dan Praktik Pendidikan 27, no. 2 (November 30, 2018): 108-15, https://doi.org/10.17977/um009v27i22018p108.

50 Judit Orgoványi-Gajdos and Judit Orgoványi-Gajdos, "Problem Solving as a Cross-Curricular Skill of Teachers," in Teachers' Professional Development on Problem Solving (SensePublishers, 2016), 1-7, https://doi.org/10.1007/978-94-6300-711-5_1. 


\section{ORCID iD}

Erni Munastiwi iD https://orcid.org/0000-0002-4962-1436

\section{REFERENCES}

Aagaard, T, and A Lund. Digital Agency in Higher Education: Transforming Teaching and Learning. New York: Routledge, 2019.

Abetang, Mary Achenushure, Romano Nereo Oguma, and Akpenka Pius Abetang. "Mentoring And The Difference It Makes In Teachers' Work: A Literature Review." European Journal of Education Studies 7, no. 6 (June 26, 2020). https://doi.org/10.46827/ejes.v7i6.3146.

Althuizen, Niek, and Berend Wierenga. "Supporting Creative Problem Solving with a Case-Based Reasoning System." Journal of Management Information Systems 31, no. 1 (July 2014): 309-40. https://doi.org/10.2753/MIS0742-1222310112.

Amoush, Abdeleh Bassam Al, and Kamaljeet Sandhu. "Digital Innovation for Transformation of Learning Management Systems at Universities." Chapter. Digital Innovations for Customer Engagement, Management, and Organizational Improvement. IGI Global, 2020. https://doi.org/10.4018/978-1-7998-51714.ch007.

Argawinata, Asep Zuhara. "Manajemen Pendampingan Guru Untuk Meningkatkan Kompetensi Pedagogik Dan Profesional Guru-Guru Mata Pelajaran Sekolah Menengah Pertama Di Kota Bandung." Jurnal Mitra Swara Ganesha 3, no. 1 (January 29, 2016). http://ejournal.utp.ac.id/index.php/JMSG/article/view/467.

Beghetto, Ronald A., and James C. Kaufman. "Classroom Contexts for Creativity." High Ability Studies 25, no. 1 (2014): $53-69$. https://doi.org/10.1080/13598139.2014.905247.

Belinova, N V. "Innovation and Education: Technologies and Perspectives." Journal of Advanced Research in Dynamical and Control Systems 12, no. 4 (2020): 130713. https://doi.org/10.5373/JARDCS/V12SP4/20201607.

BPS. “Badan Pusat Statistik Kabupaten Nunukan.” Badan Pusat Statistik, 2016.

Chua Yan Piaw. Kaedah Dan Statistik Penyelidikan: Kaedah Penyelidikan - UM Research Repository. McGraw-Hill Education. 2nd ed. Malaysia: Graw-Hill Education, 2011.

Davies, Dan, Divya Jindal-Snape, Chris Collier, Rebecca Digby, Penny Hay, and Alan Howe. "Creative Learning Environments in Education-A Systematic Literature Review." Thinking Skills and Creativity 8, no. 1 (April 2013): 80-91. https://doi.org/10.1016/j.tsc.2012.07.004.

Dobbins, Kerry. "Teacher Creativity within the Current Education System: A Case Study of the Perceptions of Primary Teachers." Education 3-13 37, no. 2 (2009): 95104. https://doi.org/10.1080/03004270802012632.

Duke, Robert A. "Their Own Best Teachers." Music Educators Journal 99, no. 2 (December 9, 2012): 36-41. https://doi.org/10.1177/0027432112458956. 
Gilhooly, Kenneth J. "Incuba Action and Intuition in Creative Problem Solving." Frontiers in Psychology 7 (July 2016): 1076. https://doi.org/10.3389/fpsyg.2016.01076.

Hajiyakhchali, Alireza. "The Effects of Creative Problem Solving Process Training on Academic Well-Being of Shahid Chamran University Students." Procedia-Social and Behavioral Sciences 84 (2013): https://doi.org/10.1016/j.sbspro.2013.06.602.

Hidayatullah, A. Digital Learning. Surabaya: UM Surabaya, 2018.

Horng, Jeou-Shyan, Jon-Chao Hong, Lih-Juan ChanLin, Shih-Hui Chang, and HuiChuan Chu. "Creative Teachers and Creative Teaching Strategies." International Journal of Consumer Studies 29, no. 4 (2005): 352-58. https://doi.org/10.1111/j.1470-6431.2005.00445.x.

Ibda, Hamidulloh. "Peningkatan Kompetensi Profesional Guru SD/MI Melalui Menulis Di Media." Tarbawi: Jurnal Pendidikan Islam 14, no. 1 (2017). https://doi.org/10.34001/tarbawi.v14i1.610.

Ibrahim, Mohd Yusri, Mat Rahimi Yusof, Mohd Faiz Mohd Yaakob, and Zurita Othman. "Communication Skills: Top Priority of Teaching Competency." International Journal of Learning, Teaching and Educational Research 18, no. 8 (2019): 1730. https://doi.org/10.26803/ijlter.18.8.2.

Ivie, Stanley D. "Self-Actualization: Its Use and Misuse in Teacher Education." Journal of Teacher Education 33, no. 5 (July 2, 1982): 24-27. https://doi.org/10.1177/002248718203300506.

Jena, Prakash Chandra, and Rinzin Dorji. "Self-Actualization And Value Orientation Among Primary School Teachers In Bhutan.” World Scientific News, no. 54 (2016): 217-39. https://www.infona.pl//resource/bwmeta1.element.psjdbd1625f8-4733-4c1b-9c18-a171f38fecc5.

Joshi, Ankur, Saket Kale, Satish Chandel, and D. Pal. "Likert Scale: Explored and Explained." British Journal of Applied Science \& Technology 7, no. 4 (2015): 396-403. https://doi.org/10.9734/bjast/2015/14975.

Juniarti, Nia, Yohanes Bahari, and Wanto Riva'ie. "Faktor Penyebab Menurunnya Hasil Belajar Siswa Pada Pembelajaran Sosiologi Di SMA.” Jurnal Pendidikan Dan Pembelajaran Khatulistiwa 4, no. 2 (February 11, 2015). https://jurnal.untan.ac.id/index.php/jpdpb/article/view/9025.

Kalyani, D., and K. Rajasekaran. "Innovative Teaching and Learning." Journal of Applied and Advanced Research 3, no. S1 (May 10, 2018): 23. https://doi.org/10.21839/jaar.2018.v3is1.162.

Kang, Nam-Hwa, Hunsik Kang, Seungho Maeng, Jongwon Park, and Eunyoung Jeong. "Teacher Competency in Competency-Focused Science Teaching in the South Korean Context: Teacher Self-Assessment Instrument Development and Application.” Asia-Pacific Science Education 6, no. 2 (December 17, 2020): 480513. https://doi.org/10.1163/23641177-bja10012.

Kools, Marco, and Louise Stoll. What Makes A School A Learning Organisation? OECD, 2017. https://www.oecd.org/education/school/school-learning-organisation.pdf. 
Langset, Inger Dagrunn, Dan Yngve Jacobsen, and Halvdan Haugsbakken. "Digital Professional Development: Towards A Collaborative Learning Approach For Taking Higher Education Into The Digitalized Age." Nordic Journal of Digital Literacy 13, no. 01 (2018): 24-39. https://doi.org/10.18261/issn.1891-943x-201801-03.

Liu, Shu Chiu, and Huann shyang Lin. "Primary Teachers' Beliefs about Scientific Creativity in the Classroom Context." International Journal of Science Education 36, no. 10 (2014): 1551-67. https://doi.org/10.1080/09500693.2013.868619.

Lopez Flores, Rene, Stéphane Negny, Jean Pierre Belaud, and Jean Marc Le Lann. "Collective Intelligence to Solve Creative Problems in Conceptual Design Phase."

In Procedia Engineering, 131:850-60. Elsevier Ltd, 2015. https://doi.org/10.1016/j.proeng.2015.12.394.

Mukhtar. "Strategi Kepala Sekolah Dalam Meningkatkan Kinerja Guru Pada SMP Negeri Di Kecamatan Masjid Raya Kabupaten Aceh Besar." Jurnal Administrasi Pendidikan: Program Pascasarjana Unsyiah 3, no. 3 (January 1, 2015). http://jurnal.unsyiah.ac.id/JAP/article/view/2873.

Munastiwi, Erni. Model - Model Pembelajaran CIPS (Creative, Independent, Problem Solving). Jakarta: Rajawali Press, 2020.

Munastiwi, Erni, Jailani Md Yunos, Maizam Alias, Sri Sumarwati, and Nor Hidayah Hamdan. "The Spending Developing Training Material Based on Creative Problem Solving and Independent Learning for Remote Area Teachers." Solid State Technology, November 1, 2020, 9189-98. http://www.solidstatetechnology.us/index.php/JSST/article/view/5591.

Souck, Emmanuel Ndjebakal, and Genevarius Nji. "The Effects of School Facilities on Internal Efficiency: The Case of Selected Bilingual Secondary Schools in Yaounde Centre." World Journal of Research and Review (WJRR) 4, no. 4 (April 2017): 41-48. https://www.wjrr.org/download_data/WJRR0404008.pdf.

Nunukan, BPS. "Badan Pusat Statistik Kabupaten Nunukan.” Accessed January 29, 2021. https://nunukankab.bps.go.id/.

Orgoványi-Gajdos, Judit, and Judit Orgoványi-Gajdos. "Problem Solving as a CrossCurricular Skill of Teachers." In Teachers' Professional Development on Problem Solving, 1-7. SensePublishers, 2016. https://doi.org/10.1007/978-94-6300-7115_1.

Pebriani, Linda, Dwi Wulandari, Rahyu Setiani, and Dian Septi Nur Afifah. "Creative and Innovative Problem Solving (Cips) Dalam Pembelajaran Matematika Berbasis Mnr (Matematika Nalaria Realistik)." Transformasi : Jurnal Pendidikan Matematika Dan Matematika 4, no. 2 (2020): 331-46. https://doi.org/10.36526/tr.v4i2.977.

Prestridge, S. "Categorising Teachers' Use of Social Media for Their Professional Learning: A Self-Generating Professional Learning Paradigm." Computers and Education 129 (2019): 143-58. https://doi.org/10.1016/j.compedu.2018.11.003.

Rahmiga, Suci. "Kurangnya Sarana Dan Prasarana Belajar Di Sekolah.” INA-Rxiv, December 6, 2019. https://doi.org/10.31227/osf.io/5ckxs. 
Ranieri, M, J Raffaghelli, and F Pezzati. "Digital Resources for Faculty Development in E-Learning: A Self-Paced Approach for Professional Learning." Italian Journal of Educational Technology (IJET) 26, no. 1 (2018): 104-18. https://doi.org/DOI https://doi.org/10.17471/2499-4324/961.

Sahari, Sahari. "Pengaruh Pendidikan, Pelatihan, Dan Pengalaman Mengajar Terhadap Profesionalisme Guru Di SMAN I Likupang.” Jurnal Ilmiah Iqra’ 9, no. 1 (2018): 62-86. https://doi.org/10.30984/jii.v9i1.599.

Schleicher, Andreas. Preparing Teachers and Developing School Leaders for the 21st Century. Edited by Andreas Schleicher. International Summit on the Teaching Profession. OECD, 2012. https://doi.org/10.1787/9789264174559-en.

Sophonhiranrak, Samoekan, Praweenya Suwannatthachote, and Sungworn Ngudgratoke. "Factors Affecting Creative Problem Solving in the Blended Learning Environment: A Review of the Literature." Procedia - Social and Behavioral Sciences 174, no. 1982 (February 2015): 2130-36. https://doi.org/10.1016/j.sbspro.2015.02.012.

Sugiyono. Metode Penelitian Pendidikan Pendekatan Kuantitatif, Kualitatif, Dan R \& D [Research Methods of Education Quantitative, Qualitative, and R \&D Approach]. 22nd ed. Bandung: Alfabeta, 2015.

Syahruddin, S, A Ahdan, and E Ernawati. "Application of Online Mode Professional Development in Enhancing Pedagogical and Professional Competencies in Early Grade Primary School Teacher.” JPP (Jurnal Pendidikan Dan Pembelajaran) 26, no. 1 (2019): 36-42. http://dx.doi.org/10.17977/um047v26i12019p036.

Syaodih, Erliany, and Cucu Lisnawati. "Pendampingan Guru Dalam Menemukan Dan Mengatasi Kesulitan Belajar Siswa Di Mts Miftahulfallah Bandung." Educare, December 31, 2018, 8-11. http://jurnal.fkip.unla.ac.id/index.php/educare/article/view/223.

Tientongdee, S. "Development of Problem-Solving Skill by Using Active Learning for Student Teachers in Introductory Physics." Journal of Physics: Conference Series 1144, no. 1 (December 2018): 012002. https://doi.org/10.1088/17426596/1144/1/012002.

Wahyuni, Rina, and Teti Berliani. "Pelaksanaan Kompetensi Pedagogik Guru Di Sekolah Dasar." Sekolah Dasar: Kajian Teori Dan Praktik Pendidikan 27, no. 2 (November 30, 2018): 108-15. https://doi.org/10.17977/um009v27i22018p108.

Woods, Peter. Creative Teachers in Primary Schools. Creative Teachers in Primary Schools. London: Taylor and Francis, 2019. https://doi.org/10.4324/9780429326639. 
This page is intentionally left blank 